INTERNATIONAL CENTER FOR PUBLIC POLICY
International Center for Public Policy Working Paper 15-03

June 2015

Reforming International Taxation: Is the Process the Real Product?

\author{
Richard M. Bird
}

GeorgaState University

ANDREWYOUNG SCHOOL 



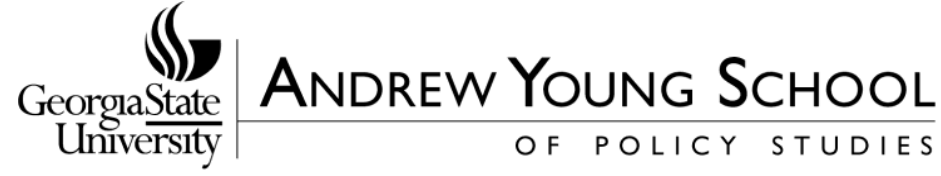

\author{
International Center for Public Policy \\ Working Paper 15-03
}

\section{Reforming International Taxation: Is the Process the Real Product?}

\section{Richard M. Bird June 2015}

International Center for Public Policy

Andrew Young School of Policy Studies

Georgia State University

Atlanta, Georgia 30303

United States of America

Phone: (404) 651-1144

Fax: (404) 651-4449

Email: hseraphin@gsu.edu

Internet: http://aysps.gsu.edu/isp/index.html

Copyright 2006, the Andrew Young School of Policy Studies, Georgia State University. No part of the material protected by this copyright notice may be reproduced or utilized in any form or by any means without prior written permission from the copyright owner. 


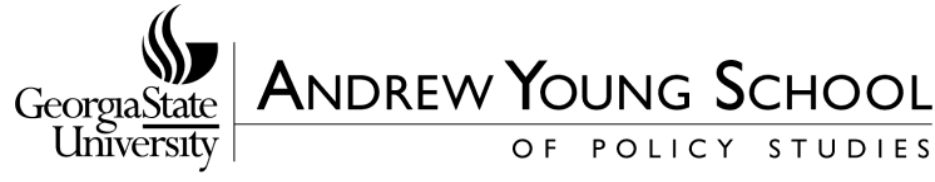

\section{International Center for Public Policy Andrew Young School of Policy Studies}

The Andrew Young School of Policy Studies was established at Georgia State University with the objective of promoting excellence in the design, implementation, and evaluation of public policy. In addition to two academic departments (economics and public administration), the Andrew Young School houses seven leading research centers and policy programs, including the International Center for Public Policy.

The mission of the International Center for Public Policy is to provide academic and professional training, applied research, and technical assistance in support of sound public policy and sustainable economic growth in developing and transitional economies.

The International Center for Public Policy at the Andrew Young School of Policy Studies is recognized worldwide for its efforts in support of economic and public policy reforms through technical assistance and training around the world. This reputation has been built serving a diverse client base, including the World Bank, the U.S. Agency for International Development (USAID), the United Nations Development Programme (UNDP), finance ministries, government organizations, legislative bodies and private sector institutions.

The success of the International Center for Public Policy reflects the breadth and depth of the in-house technical expertise that the International Center for Public Policy can draw upon. The Andrew Young School's faculty are leading experts in economics and public policy and have authored books, published in major academic and technical journals, and have extensive experience in designing and implementing technical assistance and training programs. Andrew Young School faculty have been active in policy reform in over 40 countries around the world. Our technical assistance strategy is not to merely provide technical prescriptions for policy reform, but to engage in a collaborative effort with the host government and donor agency to identify and analyze the issues at hand, arrive at policy solutions and implement reforms.

The International Center for Public Policy specializes in four broad policy areas:

- Fiscal policy, including tax reforms, public expenditure reviews, tax administration reform

- Fiscal decentralization, including fiscal decentralization reforms, design of intergovernmental transfer systems, urban government finance

- Budgeting and fiscal management, including local government budgeting, performancebased budgeting, capital budgeting, multi-year budgeting

- Economic analysis and revenue forecasting, including micro-simulation, time series forecasting,

For more information about our technical assistance activities and training programs, please visit our website at http://aysps.gsu.edu/isp/index.html or contact us by email at hseraphin@gsu.edu. 


\title{
Reforming International Taxation: Is the Process the Real Product?*
}

\author{
Richard M. Bird \\ Emeritus Professor, Rotman School of Management, University of Toronto.
}

\begin{abstract}
The reform of international taxation -- how national tax systems interact with each other - is an issue that is always technically complex, often economically significant, and sometimes politically explosive. Some expect major changes in international taxation in the near future but no one yet knows what changes might made or when, how, and how effectively they might be implemented. Instead of speculating about such matters, this paper considers the process by which countries are attempting to reform international taxation problems, essentially through complex technical and political negotiations intended to produce an improved set of "soft" law arrangements, adherence to which will, as in the present system, be essentially voluntary. The current process, although under the aegis of the OECD, is considerably more inclusive than earlier negotiations on international taxation, which were largely between developed countries that were predominantly capital exporters. Greater inclusivity may make negotiations more difficult to conclude successfully but it may also result in a system that will be more widely accepted as fair. Moreover, experience gained through the present prolonged and intensive negotiations on international taxation may perhaps suggest a more fruitful approach to dealing with such other "global public goods" problems as climate change.
\end{abstract}

Key words: international tax; OECD; negotiation; tax treaties; international relations

JEL codes: H25; H26; F5; K2

* An earlier version of much of the argument may be found in the concluding sections of Bird (2015a). 
International taxation - or its absence - has been much in the news recently. The headline message that multinational corporations exploit holes and havens in the current system of international taxation to dodge national attempts to tax corporate profits by has clearly been heard. ${ }^{1}$ Many politicians in many countries have promised that something will be done to fix this problem. However, as yet it is far from clear what can or will be done. One reason no quick fix is possible is because there is no such thing as an "international tax." The reason is simply because there is no international government. Because there are only national (and subnational) governments there are only national (and subnational) taxes. ${ }^{2}$ Of course governments impose taxes on sales and income flows that cross borders. ${ }^{3}$ When there is a border cross-border transactions are potentially subject to more than one tax system. The international tax system is thus really shorthand for a set of separate and different national tax systems that incorporate features intended to deal with cross-border flows and are often, though not always, linked through a complex set of treaties. There is no World Tax Authority, no World Tax Code, and no one in charge.

International taxation thus is about how national tax systems interact with each other - an issue that is always technically complex, often economically significant, and sometimes politically explosive. As a rule solutions to international problems are possible only when countries are prepared to give up a certain degree of sovereignty. History tells us that wars have often been fought about who gets to make the international rules. It is not surprising that resolving conflicts about fiscal sovereignty has usually been a prolonged and painful process. As with other unpleasant and difficult tasks, international tax

\footnotetext{
${ }^{1}$ The discussion here focuses on the taxation of corporate income, the main subject currently under discussion in the international arena.

${ }^{2}$ Levies like those paid by by member states to the European Union (EU) - which are discussed briefly later -- are sometimes called 'supranational taxes.' Many multinational organizations like the United Nations (UN) are also supported by levies on members, and many proposals for various other forms of regional and even global 'taxation' have been floated over the years (as discussed in Bird 2015a). However, all attempts to move such levies in a more 'tax-like' direction have so far failed and in fact all existing 'international' levies are really voluntary contributions by participating nations (Sandler 1998; Barrett 2007).

${ }^{3}$ To keep the discussion within bounds, no further mention is made here either of the international problems that arise with consumption taxes or of the cross-border problems that rise with subnational taxation, although both these areas are discussed briefly in Bird (2015b).
} 
reform only receives attention when it cannot be avoided, and the usual result of attempts at such reform, often after decades of negotiation, has been some sort of compromise that seldom fully satisfies all parties and usually gives rise to other problems and another round of discussions. ${ }^{4}$

The fairness, efficiency and effectiveness of the international tax system have long been cause for concern. Its development over the last century is episodic -- a picture of "punctuated" rather than steady incremental change (Mahoney 2012), with incremental changes gradually leading to a balance that holds for some time and then comes under pressure, leading to further incremental change and a new - though again transitory - equilibrium. The framework of the present system was first established after the First World War, under the aegis of the League of Nations, itself a product of that war, as was the growing importance of the income tax. The key elements subsequently put in place to rationalize and unify the bits and pieces that constitute the international tax system were introduced after the Second World War, largely under the auspices of the OECD, which was itself established in the aftermath of the war during which income taxes had become much more important in many developed countries. $^{5}$

The initial motivation behind both these post-war efforts to establish a more coherent international tax system was chiefly to alleviate the double taxation of cross-border income flows. As the result of decades of negotiation both between countries as well as between taxpayers and the various national tax authorities, this goal was largely achieved during the 1960s and 1970s under the aegis of the OECD. ${ }^{6}$ In the process of achieving the goal of alleviating double taxation, however, inadequate attention was perhaps paid to ensuring that international income flows were being fully taxed by anyone. It is this

\footnotetext{
${ }^{4}$ As anyone who lives in a federal or decentralized country knows, much the same can be said with respect to subnational taxes, as discussed at length in, for example, in the country case studies in Bizioli and Sacchetto (2011).

${ }^{5}$ The history is set out in Picciotto (1992) and Rixen (2008); for an interesting personal account by a principal actor in many of the developments during this period, see Carroll (1978). As suggested later, perhaps the most useful analytical framework within which to view this history is as one of developing a continuously evolving 'transnational legal order' (Genschel and Rixen 2015).

${ }^{6}$ Parallel discussions at the UN made more effort to incorporate the interests of developing countries (Surrey 1978) but had much less influence on the development of the treaty system than the OECD discussions.
} 
problem - the under-taxation of international income flows owing to "base erosion and profit shifting" or BEPS, as the $\operatorname{OECD}(2013 a, b)$ now calls it - that has moved to the headlines and consequently to the top of the international fiscal agenda over the last few years, spurred on by both the emergence of major new players in the world economy and the strains arising from the financial crisis beginning in $2008 .^{7}$

To date, the main visible results of the recent concern with international taxation have been innumerable international meetings, with the OECD again taking a leading role in the process. At the time of writing, this process is far from complete. Although many seem to expect that major changes in important aspects of the present system may be made in the near future, there is far less agreement on the nature of such changes, let alone on when, how, or how effectively they might be implemented. Is the current 'soft governance' approach to resolving international tax issues likely to produce politically acceptable, technically feasible, and economically efficient and effective results? And whether or not it does, are any feasible alternative approaches likely to produce better outcomes? ${ }^{8}$ This paper focuses on the second of these questions, leaving speculation about the desirability or practicality of the unknown answers to the first question aside and emphasizing that in many ways the most important aspect of the present discussion of international tax reform may be not so much what is done in the end but rather how it is done - the Process, not the Product.

The process through which we deal with issues relating to fiscal sovereignty has not received as much attention as it deserves. The process is important because it shapes how and to what extent reforming international taxation will be successfully achieved. But it is also important because if it is even mildly successful it may prove to be an important step towards achieving the kind of more inclusive and

\footnotetext{
${ }^{7}$ For the latest from the OECD on this issue, see http://www.oecd.org/tax/beps.htm

${ }^{8}$ The discussion of this issue draws heavily on an excellent recent review of governance with respect to international tax issues by Eccleston (2012). No attempt is made here to discuss, let alone resolve, the many complex substantive issues involved in reforming the international tax regime. For a very small sampling of the vast literature on issues in international taxation in recent decades, see e.g. Picciotto (1992), Avi-Yonah (2007), Cockfield (2010), and Shaviro (2014).
} 
effective institutional framework the world needs to deal more adequately than it has so far done with the fundamental underlying problem of providing such critical "global public goods" as climate change, keeping the peace, and raising the level of human welfare in this fractious world. ${ }^{9}$ The nature, inclusivity and success (or otherwise) of the complex evolutionary process of inter-state (and interinterest group) negotiation and compromise may, if we are lucky, eventually yield some kind of acceptable and perhaps adequate "soft governance" solution to international tax problems. More generally, this approach may be about the best we can do more generally with respect to the critical task of adjusting, slowly and painfully, the largely $19^{\text {th }}$ century political structure based on sovereign nation-states into one at least a bit more capable of coping with the reality of supranational problems in the increasingly interdependent world of the $21^{\text {st }}$ century.

\section{The Reality of International Taxation}

There is nothing new either about global problems or our reluctance to deal with them. Over a decade ago, Sandler $(2001,107)$ suggested that "the design of supranational structures is about to enter a new era in which nations may be prepared, for a few specific activities, to sacrifice some autonomy." This conclusion, although carefully hedged, now seems to have been too optimistic. Some now think, as a writer in The Economist recently put it, that "the forward march of globalisation has paused since the financial crisis, giving way to a more conditional, interventionist and nationalist model” $(I p, 2013,3)$ and that "the fate of globalisation rests on whether America, China and the rest of the world see open borders as being in their national interest" (Ip 2013, 19). Even this more restrained view may be too optimistic. The extent to which sovereign states agree to give up any degree of sovereignty remains, as

\footnotetext{
${ }^{9}$ For interesting and useful discussions of these and other candidates for global public good status, see the studies collected in Kaul, Grunberg and Stern (1999), Kaul et al. (2002), and Kaul and Conceicao (2006), as well as Kaul (2012), Sandler (1997,1998, 2002) and Barrett (2007) -- although not everything discussed in these sources is strictly a global public good defined as an outcome that makes "people everywhere better off" (Barrett 2007, 1).
} 
it has always been, very limited and dependent on what those who control political decisions think they gain from any deal.

The strengthening of democracy in significant parts of the world over the last few decades may in some ways make it harder rather than easier for states to compromise. The United States, for example, refused to join the post-World War I League of Nations although it had initially been created by American initiative. More recently, it failed to ratify the Kyoto accord. On the other hand, U.S. leadership in the Marshall Plan and other reconstruction and development initiatives after World War II points in a different direction. Generally, however, increased democracy means that the interests of the many (or at least the interests of many influential groups) and not just those of the ruler (and close associates) must now be taken into account. Increased inclusivity, whether in domestic or international politics, cuts two ways. On one hand, government decisions may be more broadly acceptable and hence sustainable over time. On the other, achieving consensus on such decisions is inevitably a longer and more complex process.

A closer look at how over the years countries have managed to smooth at least some potential conflicts in the fiscal area may offer useful lessons not only with respect to the future of the current international tax discussions but also for the prospects of improved global governance in general. For example, one proposal that has been urged by some as the best and simplest way to resolve the current problems with taxing international income is to adopt what is often called unitary taxation (Picciotto 2013) - a shorthand expression for a system of world-wide reporting of corporate income, with profits being apportioned in accordance with an agreed formula.to the different jurisdictions in which corporations are active. Over the years, the unitary approach has often been argued to be a more sensible way to deal with the reality of firms that operate across national borders than the currently entrenched system 
of separate entity accounting, under which a branch or subsidiary within any jurisdiction is accounted and generally taxed as a separate entity. ${ }^{10}$

Under the current approach transfer prices must be estimated for transactions with other parts of the corporation or group, with the objective being to produce a result as close as possible to that which would emerge if all such prices were set at arm's length by unrelated companies. In practice, such estimates are usually complicated, arguable, and somewhat arbitrary. The outcome of the exercise may bear as little relation to reality as does the underlying assumption that the parties on both sides of such transactions are independent entities rather than components of the same company. In contrast, the formulary apportionment approach used to allocate profits to subnational jurisdictions within federal countries like the US and Canada, which is closely related to the unitary approach, is simpler in both concept and practice, attributing profits (or losses) to each jurisdiction based on such more observable and measurable factors as the proportion of sales, assets or payroll in that jurisdiction. ${ }^{11}$ There are clearly good arguments in principle for this approach (Picciotto 2013). But the lengthy history of international taxation suggests that a more likely outcome of the present discussion is continuation of the traditional process of marginal adjustments by specific countries attempting to cope with specific problems in specific ways. ${ }^{12}$

The current approach to taxing cross-border transactions implicitly rests on a stylized set of facts: (i) small and evenly-balanced flows of cross border investments; (ii) relatively small numbers of companies engaged in international operations; (iii) heavy reliance on fixed assets for production; (iv) relatively small amounts of cross-border portfolio investments by individuals; and ( $v$ ) only minor concerns with international mobility of tax bases and international tax evasion. These assumptions do not reflect

\footnotetext{
${ }^{10}$ As a personal example, Bird (1988) favored this approach.

${ }^{11}$ For a recent review of formulary approaches in federal and regional settings, see Siu et al. (2014).

${ }^{12}$ For a good recent appraisal of the prospects for moves in the 'unitary' direction, see Durst (2015).
} 
current reality. Many business operations have changed drastically as production has become more dispersed, with different (though integrated) operations taking place - in reality, or at least in terms of fiscally relevant paper -- in different countries. The share of total value-added - the ultimate tax base -arising from services and intangibles has increased to the point that it is difficult to locate the source of corporate income or taxable activities sufficiently clearly in space (or time) for any country to be able to tax that income with a demonstrably superior relative claim than other countries involved. ${ }^{13}$

The commonly accepted arm's length standard for measuring and allocating the international income of business enterprises among taxing jurisdictions is intended to provide a basis for national taxation of the "correct" share of such income. To do so, however, traditional conventions based on separate entity accounting are applied to multinational and global corporations that consolidate commercial activities organized and operated along functional lines according to centers of business interest. To assume that such economic units can meaningfully be divided into legally separate components for tax purposes flies in the face of reality. Multinational enterprises exist precisely to avoid the costs and limitations of dealings between unrelated parties. The economic rent such firms obtain by operating as a single economic entity that avoids these costs and limitations cannot be properly captured and allocated by the prevalent tax approach.

National tax administrations need effective institutional ways to tax such enterprises. However, characterizing them in a way that directly contradicts their essence and manner of operation as the current approach to international taxation in effect does is not a promising path to sustainable tax policy. Efforts to make this approach workable have required increasing reliance on a series of fictional assumptions initially conceived as expedient ways to adjust for possible profit distortions attributable to common control. The weaknesses inherent in this approach have become so magnified and

\footnotetext{
${ }^{13}$ This paragraph, like much of the remainder of this section, follows Bird and Wilkie (2013).
} 
compounded by the continuing tax planning maneuvers of multinational enterprises that its connection to reality is now often too tenuous to be believable. ${ }^{14}$

A number of alternative paths to dealing with cross-border tax issues are conceivable. For instance, one approach might be to focus on establishing as clear a link as possible between taxes and expenditures so that those who pay, those who benefit and those who decide are essentially in agreement. ${ }^{15}$ The problem with this approach is once again that there is simply no effective political unit within which such fiscal contracts between countries and interests can be negotiated. One cannot have an effective, coherent and coordinated international tax regime in the absence of an accepted overriding system of global governance in at least some 'soft' form. Unfortunately, as yet such a system remains more a dream --or perhaps, for some, a nightmare -- than a reality.

Another possible approach may be to establish small taxes with relatively modest goals which can be piggybacked on levies imposed by existing fiscal and political institutions and implemented through a network of explicit and implicit agreements between states. ${ }^{16}$ As always in the international context, however, the key question is how such agreements can be enforced. The answer is that they cannot unless and until the contracting parties, particularly the larger and more politically and economically important ones, fully accept the agreement in question and voluntarily agree to apply it to themselves.

\footnotetext{
${ }^{14}$ For example, the well-known OECD Transfer Pricing Guidelines (OECD 2010) started out as a way to provide valuation guidance in identifying when and to what extent there were distortions in the distribution of profit within a group attributable to the possibilities for manipulation engendered by common control. It is far from clear that the application of these guidelines as transactional accounting standards is or ever can be adequately matched by the legal concepts and tax law provisions needed to give them life.

${ }^{15}$ For an elaboration of this approach at the sub-national level, see Bird and Slack (2014).

${ }^{16}$ This approach comes close to a classic definition of an international regime (Krasner 1982, 186) as "implicit or explicit principles, norms, rules and decision-making procedures around which actors' expectations converge in a given area of international relations." For useful recent reviews of the global governance literature as it applies to international tax issues, see Eccleston (2012) and Genschel and Rixen (2015).
} 
If they are unwilling to do so, others are likely to be even less willing to agree to be penalized when their time comes. ${ }^{17}$

Those who wish to reform the international tax system need to focus more on issues of 'process' (how things get done) than 'substance' (what gets done) because what gets done in practice depends in the end on the extent to which everyone thinks that those who sign up are really committed to do what they say. If some of the contracting parties fundamentally do not accept that the process through which the agreement was reached was sufficiently fair and inclusive for them to be bound by its outcome, it matters little how sound that outcome may be in principle. ${ }^{18}$ It will not be achieved in practice.

Countries face a difficult dilemma with respect to politics and economics In a globalizing world. There is no way to have both autonomous nation-states and full global integration. The power to tax is a key attribute of the modern nation state. No state will readily forgo that power. The present international tax regime is the outcome of many previous attempts to reconcile increasing globalization and national sovereignty. As experience over the last century demonstrates, as a rule countries are more willing to forgo potential economic benefits for their citizens than to give up state power. It is no surprise that they are even less willing to give up autonomy in order to make other people better off. Much of the discussion of international tax reform does not face up adequately to this central problem in a world with no world government to impose world taxes. Any international tax system works only to the extent that it is both widely acceptable, particularly (but not solely) by the more important countries. Moreover, it must also be fit to be implemented by real (and sometimes very imperfect) national tax regimes and not only by some non-existent (perfect) supranational entity.

\footnotetext{
${ }^{17}$ For example, the 'moral force' of the EU's limits on 'acceptable' debt and deficit levels was undoubtedly weakened substantially when France and even Germany demonstrated some years ago that they felt free to breach these limits when it was convenient for them to do so.

${ }^{18}$ Hirschman (1971) discusses how and why countries may sign up to policies in which they do not believe and the various ways in which the resulting "cognitive dissonance" may work out.
} 
Yet another possible approach to international tax reform may be to focus on the practical regulatory dimension of the emerging new world economic and tax policy order. The seeds of an international approach to tax regulation have already been sown in the form of the various more or less formal interactions of tax policy and regulatory authorities organized through the OECD's Global Tax Forum and other groupings. ${ }^{19}$ Countries have increasingly been sharing financial and tax information through a plethora of Tax Information Exchange Agreements (TIEAs) as well as the information exchange arrangements contained in bilateral tax treaties. In principle such agreements limit the possibility that income can be hidden from interested tax authorities. Success in doing so remains elusive in part because it is almost never in the interests of hard-pressed tax officials to place the interests of other countries very high on their priority lists. ${ }^{20}$

One way or another, however, tax administrators and tax policy-makers around the world are becoming increasingly well informed about and influenced by developments and approaches in other countries. But no country is going to abandon tax claims in favor of the interests of another country when it comes to taxpayers with observable connections to both unless there is a significant reason to do so in its own interests. Tax policy-makers and tax administrators act, at best, in the interests of the national welfare of their citizens, not some abstract conception of world welfare. At worst, they may act mainly in the interests of those with substantial economic or political influence or even their own private interests.

\footnotetext{
${ }^{19} \mathrm{~A}$ recent overview of many of the issues discussed here may be found in OECD (2013a). Among the relevant groups created in recent years are the Forum of Tax Administrators (FTA), a panel of national tax administrators established in 2002 by the OECD's Committee on Fiscal Affairs to promote dialogue between administrations; the Leeds Castle Group, a group of tax administrators from a number of major countries, including some non-OECD countries like China and India, who meet regularly to discuss mutual compliance problems; and the Joint International Tax Shelter Center established by the U.S., U.K., Canada and Australia to develop and share information on abusive tax avoidance.

${ }^{20}$ For an optimistic view of the prospects for future international tax information exchange and cooperation, see Grinberg (2013). For considerably more restrained appraisals of these prospects from two quite different perspectives, see Shaviro (2014) and Eccleston (2012).
} 
The axis of interest of countries acting as if they were economic actors in relation to each other through their respective taxpayers underlies the internationalization of tax policy and rules and has led to a complex administrative web of tax treaties, information sharing, advance pricing agreements (APAs) on transfer pricing between taxpayers and tax administrations, dispute resolution procedures (Altman 2005), and the like. Observing how international taxation currently works it is hard to believe that anyone involved has been thinking very clearly about the objective of international tax policy. Provisions like those on controlled foreign corporations and foreign tax credits found in national tax laws as well as the many tax treaties that now exist seem to be at best pragmatic attempts to accommodate the many physical and legal ways in which commercial activities actually take place. Often this is done simply by adding on particular features to tax laws developed essentially for domestic purposes without much attention to how such new international features interact with domestic tax policy objectives or achieve anything with respect to potentially more global objectives.

Nonetheless, although perhaps no one can be ever quite sure what is going on and why in the international tax arena - let alone what should go on in some normative sense -- for many years taxpayers and their various governments have one way and another, through language and through commercial relations, been communicating with each other to the point that, at least in conceptual terms, it seems not unreasonable to conclude that a sort of loose confederation of a number of more developed national tax systems has emerged. This construct is not all that different in some respects from the more formal arrangements that often exist within federal countries to co-ordinate the contemporaneous application of central and subcentral taxes on similar income and consumption bases, apart from the obvious and important difference that there is no world equivalent to the central government. 
One reading of the extensive literature on taxation in federal states, like the broader literature on decentralization in general, is that what may at first seem to be the costly duplication of functions and unnecessary costs of coordination inherent in a decentralized decision system compared to one with a single monopoly decision-maker may provide a useful degree of redundancy in a complex system coping with constantly changing conditions (Lindblom 1969). Polycentric decision-making may also increase the chance that innovative solutions to complex and seemingly intractable problems may emerge, precisely because different units are involved in attempting, independently (but not in ignorance of what is going on elsewhere) to deal with similar problems (Feldman 2015). To some extent, similar arguments may perhaps apply even in the inherently less coordinated and even more heterogeneous and changeable international setting.

Of course, a quite different and less optimistic interpretation of the international system is also possible. Current international tax rules and practices may be seen not as a more or less acceptable compromise (given coordination costs and conflicting objectives) of a negotiation process between rational actors with some similar and some different interests but instead as little more than a last ditch rationalization for clinging to outmoded practices and constraints. Only time will reveal which characterization is closer to reality.

Taking the more positive perspective, countries seem increasingly to be realizing that the reality of competing tax systems needs to be taken into account in making national policy decisions. As such awareness continues to deepen and evolve one possible outcome may be that such theoretical concepts as inter-nation equity (fair international sharing arrangements) may become more important. ${ }^{21}$ At present, however, as Lang and Owens (2013) note, the international tax regime falls far short of satisfying any conceivable distributional goal.

${ }^{21}$ For a useful recent discussion of inter-nation equity, see Brooks (2009). 
Tax treaties, for example, are mainly geared to the interests of richer (residence) countries. Some observers such as Thuronyi (2010) have suggested that most developing countries are better off not to sign such treaties, essentially because the degree of 'reciprocity' (reciprocal gain) critical for attaining a mutually beneficial outcome is unlikely to be present. ${ }^{22}$ Even within the 'residence' countries that have historically dominated the international tax world, treaties inevitably reflect the fundamental tension between two conflicting objectives: to raise more revenues from residents and at the same time to attract more investment from abroad. Both within and between countries more explicit and transparent discussion and, to the extent possible, agreement as to who should tax what and how much seems needed for even the most important countries to be able to tax international transactions effectively.

The current OECD-led effort to establish a more leak-proof international tax regime is unlikely to produce any lasting solution to the basic trilemma of problems (Genschel and Rixen 2015) - tax sovereignty, tax competition, and double taxation - that have produced the current system. Indeed, considerable as the current efforts are, they may be unable to produce any effective solution unless the political foundations of the international tax regime can be strengthened, which does not seem a likely outcome. Without no viable supranational enforcement authority, the critical issue of how to administer any agreed system through inevitably imperfect national tax regimes must be resolved because even the best-designed international tax regime will not work without a solid institutional foundation. Substantial efforts are needed to ensure that none of the key parameters in any new system are as porous or indefinite as the apects of the existing system that have engendered so much

\footnotetext{
${ }^{22}$ We return to the importance of 'reciprocity' later in the paper. Of course, all such generalizations must be taken with a grain of salt. The international tax problem can be analyzed as a 'coordinative game with distributive implications' (Rixen 2008). As with all such games, whether a treaty is a win-win situation for both parties depends on many critical factors such as the precipitating event leading to the initial discussion, the sequence of actions, and the different roles taken by different players at different points in the evolution, often by fits and starts, toward the (temporary) equilibrium solution of a treaty.
} 
controversy and litigation. The system as a whole must be not too complex for even diligent and honest self-enforcers and the best tax officials to enforce -- and thus impossible for less well-off countries to implement. Such problems cannot be resolved quickly or easily whether a radical policy change like the unitary approach is chosen or we continue with the continuing evolutionary and accretionary process of change - 'punctuated gradualism' (Mahoney 2012) - that seems a more likely outcome of the current process. Genschel and Rixen $(2015,180)$ characterize the international tax issue as one that has produced "...an infinite recursivity of global lawmaking, enactment and change" over the last halfcentury or so. It is unlikely to change in the near future.

No country can now think of what tax regime is best for it in isolation from the taxes that exist in other countries. The current international tax and trade regime is the result of decades of effort to reduce both the distortionary effects of multiple trade taxes and the use of taxes to influence trade and investment. The questions debated by the League of Nations experts in the 1920s, like much of the language of that debate, are in many respects eerily similar to many of the current debates at various international and cross-national levels about how to grapple with the even more difficult (and considerably broader) problems that arise from the increasingly large share of income arising from such 'footloose' factors as intangibles and financial structuring. The problems are more important than ever before. The question is whether we have developed any better way to deal with them than we had a century ago. The answer is not yet clear.

Countries have always competed with each other for shares of a shared tax base. They are going to continue to do so. Historically, when countries' interests collide solutions have been reached either through conflict or, in one form or another, through cooperation. Few issues are more important in shaping tax policy today in many countries than deciding how best to cope with the changing international economy. The extent to which and the manner in which the issues currently at the 
forefront of international tax discussions are resolved will have important implications - for better or for worse -- not only with respect to the future development of public policy in many countries but also with respect to how independently countries can behave in fiscal terms in the modern world.

\section{The Way Forward}

Until countries in the interest of their own survival - or perhaps the well-being of their citizens -- are willing to forgo sufficient sovereignty to enable the development of a more effective world governance structure, matters are unlikely to change much. Those who put forth proposals for radical reform have usually done so with the best intentions and for reasons that are worth taking seriously. Without utopian thinking about what a better world might look like and how we might get there, and without efforts by some to persuade the rest of us of the importance of such matters, humanity would perhaps have never left the caves, and we would find it even more difficult to sort out how to cope with the difficulties and problems that those who live on this planet currently face. Moreover, some of the ideas developed in the back of academic caves have at times played an important and even critical role in shaping the ideas and actions of policy-makers by establishing focal points around which important issues can be structured and understood. ${ }^{23}$

As successful revolutionaries soon learn, however, the thinking, skills and efforts needed to overthrow the old regime are seldom those needed to establish a sustainable - let alone better - new world. Not only is the way forward unlikely to be quick or simple but the path to progress is more likely to be through the further evolution of the sort of soft international context in which international tax matters

\footnotetext{
${ }^{23}$ Not always necessarily with better outcomes, of course, as Keynes $(1936,383)$ famously noted when he said that "Madmen in authority, who hear voices in the air, are distilling their frenzy from some academic scribbler of a few years back."
} 
are now discussed than the unreachable dream of creating an effective supranational tax authority (Tanzi 1995).

When solutions to problems are hard to find, sometimes the best approach may be to approach them differently. Taxation in any country, like the world itself, is never perfect and always in need of constant revision and interpretation. Even the most technically perfect legal designs or technological solution, whether intended to increase tax transparency or to foster international tax cooperation is unlikely to work perfectly, especially in a changing environment. The best and most sustainable approach to reforming international taxation is less to adopt ever more cleverly innovative tax designs than to improve the way in which such problems are defined and resolved.

One essential condition for a sustainable solution in a world in which all have (or should have) some voice is greater inclusivity. More of those affected in a significant way by decisions must be heard -- and know that they are heard -- in reaching those decisions. Of course, the more voices heard the longer and more complex the negotiations are likely to be. Moreover, even the best, most prolonged and thorough consultation process may never reconcile some to accepting decisions to which they object. But when decisions are reached as part of an on-going reciprocal process, with some losing on this and others on that front, they may prove acceptable over time even to those who lose than are decisions that losers can view as having been imposed from above or outside. ${ }^{24}$

A major failing of the current international tax system from this perspective is the extent to which it reflects primarily the interests of the major developed countries. Unfortunately, many current proposals to reform the international tax system suffer from the reverse problem: they seem to represent only the interests of the poorer emerging countries to the detriment of those who are (or think they are) expected to bear most of the burden. Christian Aid (2013) noted that "tax justice" is "the

\footnotetext{
${ }^{24}$ See the discussion at note 19 above.
} 
lifeblood of functioning democracies" and lies "at the heart of the social contract between citizens and the state." Viable and sustainable democracies do indeed depend to an important extent for their sustenance on what is in effect a fiscal contract between citizens and state. A tax system broadly accepted as fair constitutes an important element of such a contract. ${ }^{25}$ However, extending this argument to the world as a whole assumes that the world can be treated as though it is a meaningful political unit -- if not a unitary state, at least a loosely federal one. It is not.

Moreover, the evidence suggests that most who live in rich countries do not care as much for those who fall outside their national group as for those with whom they share citizenship (or residence). People everywhere identify more with those they know than with those they do not. ${ }^{26}$ Injustice within one's accepted (or legal) group is taken far more seriously as a political matter than injustice between one's group and those outside one's group. Foreign aid is thus a fringe budgetary outlay in developed countries, most of which have been reluctant to hand over more than a fraction of even this small amount to multilateral administration. People may be moved by appeals to their better nature, especially when the reality of crisis is placed before their eyes. But there is little evidence that any significant number of citizens in the developed world are willing to increase their tax burdens in order to fund international income transfers to even the most worthy candidates, let alone to hand over such funds to an international agency to decide who gets how much. ${ }^{27}$ People are equally unwilling to let foreigners decide which country gets 'their' tax revenue. The serious imbalances in access to resources found in the world today cannot be rectified without major and improbable changes in power relationships both between rich and poor countries (as well as within countries).

\footnotetext{
${ }^{25}$ Bird and Zolt (2015) explore this idea in the context of Latin America.

${ }^{26}$ The proposition stated in the text, although it seems plausible - and has long been discussed from many different perspectives by philosophers (Wellman 2000; Coons 2001), psychologists (Ashmore, Jussim and Wilder 2001), and economists and political scientists (Gradstein and Konrad 2006; United Nations 2006) - is of course not irrefutable.

${ }^{27}$ As Kaufman,McGuirk and Vicente (2012) show, however, this does not mean there is no support for different forms of aid, and perhaps more of it, in at least some countries.
} 
A small but useful step in this direction would be to increase the transparency and openness of international fiscal arrangements. Considerable attention has been paid in recent years to increasing the transparency of both national and international fiscal arrangements with respect to extractive industries in particular. Over thirty countries - all but Norway with relatively low incomes -- are now classified as compliant with the Extractive Industries Transparency Initiative (EITI). Another 17, including the UK and the US, are members but do not yet fully implement the required reporting system. ${ }^{28}$ Many of the world's largest oil and mining companies are also listed as supporters (stakeholders) of EITI, which reports data on payments to governments from companies based on separate reports from companies and governments as reconciled by an independent auditing firm (selected by the country). Although clearly much could be done to improve the effectiveness and impact of this pioneering effort (Anayati 2012), efforts to extend such work more broadly in terms of coverage of both companies and countries may in the absence of any real system of global governance perhaps turn out to be an effective way to improve the taxation of this sector. ${ }^{29}$

Much the same may be said of efforts to develop workable and perhaps eventually persuasive ways of using national taxes (among other instruments) in ways that may, as Pogge $(2011,352)$ argues, slow the “...depletion of natural resources and the deterioration of our environment while also greatly reducing the huge unjust burdens now imposed on the world's poor." More information and better understanding may, over time, lead to more recognition of the connections between such key questions, then to the kinds of attitudinal changes and finally, perhaps, to political responses that may begin to move both national and international systems towards a better world for all. Of course, no one knows how quickly even the most strongly evidence-based propositions about issues such as climate change and poverty relief or the fairer (however defined) distribution of international tax revenues are

\footnotetext{
${ }^{28}$ See the official web page at http://eiti.org/.

${ }^{29}$ For an example of a recent proposal for international tax reform in this sector that in part reflects the new openness about resource taxation evidenced by this initiative, see Siu et al. (2015).
} 
likely to lead to action in a world that has all too often rejected such arguments when they conflict with prior belief systems.

Those who anticipate simply incremental improvements in international taxation must similarly believe that reason will eventually triumph. But reason also suggests that emphasizing the redistributive aspects of proposals to reform international taxation is unlikely to be a major selling point for the people and politicians of rich countries. Those who wish to change the world would do better to emphasize proposals that provide not just real gains for the less fortunate but some visible gains for almost everyone. For instance, increases in taxes on carbon emissions may perhaps at some point come to be seen as sufficiently beneficial in the eyes of enough groups to overcome the often more immediately politically attractive options of regulation and subsidy -- not to mention the even more popular option of doing nothing (Bird 2015a). Countries, rich and poor, may come to see the benefits of taxing bads of all sorts (pollution, congestion, health-damaging consumption) rather than, as some now do, subsidizing them. At times it may even make sense to tie such levies to certain expenditures: for example, properly charging for transport may be feasible only if those who pay can see some direct and visible compensation, for instance through reductions in congestion. Unless some 'win-win' element can be introduced into international tax discussion, so that those who decide such matters can see some benefit for those whom they represent, substantive changes are unlikely to emerge from the process.

Even if the current efforts to reform international taxation do produce results, however, redistribution from rich to poor countries is unlikely to be a major result, since most countries have as yet not managed to do much such redistribution through direct fiscal means even within their own borders. As experience both within and across countries has shown, the major factor reducing both poverty and inequality has been generalized and sustained economic growth. As Piketty (2014) and others have 
recently emphasized more could and should be done fiscally to improve distributive outcomes. ${ }^{30}$

Nonetheless, as economists have long argued, both theory and experience seem to suggest that the most important fiscal contribution to making the poor less poor, the rich poorer, and the middle class larger and better off may well be to reduce taxes on capital income rather than to focus, as much of the international discussion has done, on how not only to divide such taxes more fairly between countries but also to increase them. ${ }^{31}$ The public intellectual debate on this matter may in the end be won by those who emphasize altruism and internationalism as higher, more moral goals, than economic growth. The practical politics of taxation at the national level are likely to remain firmly dominated by selfinterest and nationalism. In the end, the result might turn out to be a 'win-lose' one, with a somewhat smaller pie being divided a bit more fairly.

The OECD-type soft consensus approach to achieving even partial and acceptable solutions to complex international issues through a lengthy and on-going process of technical work and policy discussions involving an increasingly large and more representative group of countries and interests has obvious limitations. But gradually extending this process and making it more inclusive remains the most promising way yet found to develop common goals, definitions, concepts, assessments and evaluations over the broad range of activities and interests affected by tax decisions. Whatever emerges from this process must be implemented, as now, by separate national laws and through bilateral treaties and may hence continue to be dominated by the search for what might perhaps be called an acceptable degree of 'perceived reciprocity' 32 - a deliberately nebulous term intended to express what treaty negotiators

\footnotetext{
${ }^{30}$ For two small looks at aspects of this question, see Bird and Zolt (2015a, 2015b).

${ }^{31}$ As Stiglitz $(2015 a, b, c, d)$ notes in a major recent theoretical study, it is important to distinguish 'wealth' as measured by Piketty (2014) from the 'capital' usually emphasized by economic theory. His work does support higher taxes on land, especially urban land, as well as improving and strengthening financial regulation on both equity and efficiency. However, although not explicitly considering the international context, he also concludes essentially that the traditional case for the generally beneficial effects on income levels and growth of lower taxes on 'real' capital remains valid.

32 This is a variant of what Sato and Bird (1975) in a much earlier discussion of the international aspects of corporate income taxation called "effective reciprocity."
} 
appear to be aiming at when they play the complex coordination game of distributing the tax base between partners in different and unbalanced initial positions and with very different interests and abilities (Rixen 2008).

In this context, the aim of the current OECD-based discussions may perhaps be characterized as attempting to reshape the 'anchors' or 'focal points' around which national and bilateral discussions of international tax matters are structured. One reason for doing so may be, for example, to move some distance away from the long-standing 'residence-source' country conflict towards a position from which both partners may have something to gain by reducing the ability of taxpayers to play one country against another often through the medium of introducing into the discussion both a number of other countries and different characterizations of potentially taxable flows. ${ }^{33}$

Global issues of justice and fairness need not be dealt with globally. They cannot be dealt with solely by nation-states. What is needed is some forum between these extremes in which such issues can be discussed and, perhaps, resolved (Sen 1999). Because the traditional closed economy analytical box no longer adequately encompasses the critical marginal (international) component of tax policy, national policy choices increasingly have to be framed outside that box. In the current international tax system relatively open developed countries have in practice gradually delegated more and more elements of national tax authority in practice to such informal arenas as associations of tax administrators and policy makers concerned with international tax issues like the on-going policy discussions reflected in OECD (2013a,b).

Although considerable and commendable efforts are being made to make these discussions more inclusive than any previous international tax discussion, it still seems unlikely that the outcome of these

\footnotetext{
${ }^{33}$ Those interested in the often incomprehensible details that make up the complex story of international taxation are again referred to the thousands of pages of material already available on www.oecd.org/beps, preferably after preparing themselves by immersion in at least a few of the sources cited earlier (e.g. in note 9).
} 
discussions will be definitive or accepted by all, let alone quickly or widely implemented. Indeed, if pushed too far and too fast, the outcome of the current process may prove to be as unsuccessful as was the earlier OECD-led attempt to attack 'harmful tax competition. ${ }^{34}$ Even if the current process eventually resulted in the establishment of some kind of nascent 'world' tax organization (Tanzi 1995) which may at most perhaps be a relatively centralized information exchange -- it is inconceivable that it would have even the very small degree of independent taxing power that the European Union (EU) now has.

Although the EU itself has no tax administration, it has since 1970 been largely funded by its own resources and is not dependent on voluntary contributions from member states. In addition to 75 percent of customs duties ${ }^{35}$ and a progressive personal income tax on its own employees, the EU has two additional sources of own-revenues. Initially, the most important source was a levy on a harmonized value-added tax (VAT) base (adjusted to be on a comparable base) in EU member states. Like customs duties, the EU share of national VAT collections is collected by national tax administrations and remitted to the EU. The rate of this levy has over the years been reduced from the initially agreed 1 percent (raised to 1.4 percent in 1986) to the current level of only 0.3 percent. Most of the EU tax burden imposed on member states -- which is currently limited to a maximum of 1.23 percent of GNP -now takes the form of a residual assessment based (essentially) on the GNP of Member States. As EU (2008) describes in detail, the multi-annual financial framework is considerably more complex than this capsule description and includes a variety of special adjustments for particular countries.

As always, who pays exactly how much for an international organization, whether regional like the EU or global like the UN, has turned out to be a highly political issue that invariably requires complex

\footnotetext{
${ }^{34}$ Eccleston (2012) discusses this earlier experience in detail.

${ }^{35}$ The other 25 percent is kept by the collecting country. The arrangements recently negotiated to finance the EU for 2014-2020 will reduce the share of the collecting country to 20 percent.
} 
negotiations between countries with differing interests and agendas. ${ }^{36}$ A recent study suggests that “...the concept of a fiscal union will only work if political integration goes significantly beyond the current state of affairs, and probably far beyond levels that would be supported by European citizens and voters" (Fuest and Peichl 2012, 9). If this can be said about the European Union after a half-century of economic union, the prospects for meaningful fiscal union or international tax reform is no different. Moreover, although strong leadership by strong states like the US will remain an essential element in resolving international tax issues it may no longer be enough - which is perhaps as well given the very different prescriptions for the future of the U.S international tax system by recent authors. ${ }^{37}$ Traditional leaders in international tax matters like the US may become less likely (and able) to take actions on their own to avoid or reduce their own perceived problems, especially when such actions may arguably preempt the sort of more broadly acceptable (less US-focused) solutions that may perhaps emerge eventually from increasingly formal joint policy actions and administrative cooperation between national administrations already under way at the OECD and elsewhere.

\section{Conclusion}

International finance, like international trade, is a matter of global concern. Consequently, so is the question of how taxes affect cross-border financial flows. Everyone, though to varying degrees, is affected over time by how well the international system works. Decades of effort have gone into building the existing complex system of regulating trade, finance, and the international aspects of

\footnotetext{
${ }^{36}$ After over two years of negotiation, a new financial framework for the EU covering the period from 2014-2020 was recently agreed. Although the same (1.23 percent) limit on EU taxation remains and almost no changes in the financing system were made, that the discussion continues is indicated by the fact that a special high-level group is to be appointed to investigate whether the system should be changed in the future (http://europa.eu/rapid/pressrelease MEMO-13-1004 en.htm). (How other international organizations are financed is discussed in Bird 2015a.) ${ }^{37}$ See, for example, Shaviro (2014), Goldberg (2013) and Kleinbard (2015).
} 
taxation - a system that many now seem to think has not done a very good job. Decades more may be needed to figure out how best to improve that system and to implement such improvements. One component of the answer may in the end be perhaps some limited form of global taxation or, more likely, more tightly coordinated uniform national taxation. ${ }^{38}$

However, unless and until most people in most major countries truly accept that they are part of a larger world polity -- if indeed that day will ever come without a world-shattering crisis - all we can do is to continue to struggle along with the patched-up and partial international system we now have, modified from time to time as new players and new interests enter the decision-making group and as that group faces new realities. If and when that system reaches a sustainable and inclusive agreement about how to treat cross-border transactions, the possible basis for a more global approach to dealing with (and financing) global public goods may at last exist. How we deal with most such problems will likely, as in the past, be not by creating new international fiscal institutions but rather through continued tinkering with the soft law framework that now underlies the international tax system - a framework that essentially depends on voluntary acceptance and enforcement by countries acting in their own interests.

It may perhaps be possible over time -- with enough effort and no doubt after prolonged and difficult negotiations -- to reach a soft solution through largely voluntary cooperation and coordination that would be an improvement on the existing situation. If most people at some level and in some degree come to believe that they have something to gain from resolving these problems, the world as a whole, fragmented and contentious as it is, may perhaps at some stage and in some manner be able to work out some way of sharing tax bases that cross borders that is broadly acceptable to those whose

\footnotetext{
${ }^{38}$ For example, there has been considerable recent discussion, and some limited action (e.g. within the EU) with respect to taxes levied specifically on the financial sector or financial transactions, as reviewed in Bird (2015a). There has also of course been a general downward trend in corporate tax rates in recent years as a result of independent domestic policy decisions that have sometimes been influenced by but not usually dominated by international factors (Kumar and Quinn 2012).
} 
cooperation is essential to reaching the intended goal. But what that solution might be, when it is achieved, and how long it will last are all as yet to be revealed.

For now, about all one can conclude is that reforming international taxation is a complex and difficult matter that will be the subject of continual discussion and negotiation for years to come. As and when most major players are willing to settle for incremental change toward a better system, the world should be able to do better than now when it comes to taxing international income flows relatively fairly and efficiently. Whatever substantive changes may emerge from the on-going process of reforming international taxation, the process itself has much to tell us about how and how well we may be able to cope with the array of complex and difficult obstacles that lie before us on the path to developing and sustaining a better world.

\section{References}

Altman, Z. (2005) Dispute Resolution Under Tax Treaties (Amsterdam: IBFD).

Anayati, S. (2012) The 'Resource Curse' and the Extractive Industries Transparency Initiative (EITI), Dissertation submitted for MA/MSc degree in Geopolitics, Territory \& Security at King's College London,

Ashmore, R. L. Jussim, and D. Wilder (2001) Social Identity, Intergroup Conflict and Conflict Reduction (Oxford: Oxford University Press).

Avi-Yonah, R. (2007) International Tax as International Law: An Analysis of the International Tax Regime. (Cambridge: Cambridge University Press).

Barrett, S. (2007) Why Cooperate? The Incentive to Supply Global Public Goods (New York: Oxford University Press). 
Bird, R. (1988) "Shaping a New International Tax Order", Bulletin for International Fiscal Documentation, 42 (7): 292- 99, 303.

Bird, R. (2015a) Global Taxes and International Taxation: Mirage and Reality, ICTD Working Paper 28, International Centre for Tax and Development, Institute of Development Studies, Brighton UK, January.

Bird, R. (2015b) “Below the Salt: Decentralizing Value-Added Taxes," in E. Ahmad and G. Brosio, eds., Handbook of Multilateral Finance (Cheltenham UK: Edward Elgar), pp. 291-333.

Bird, R. and E. Slack (2014) “Local Taxes and Local Expenditures in Developing Countries: Strengthening the Wicksellian Connection," Public Administration and Development 34 (4): 359-369.

Bird, R. and S. Wilkie (2013) "Designing Tax Policy: Constraints and Objectives in an Open Economy," eJournal of Tax Research, 11 (3):

Bird, R. and E. Zolt (2015a) "Fiscal Contracting in Latin America," World Development, 67 (March): 323335.

Bird, R. and E. Zolt (2015b) "Taxes, Spending and Inequality in Canada and the United States: Two Stories or One?" Osgoode Hall Law Journal, 52 (2): 401-426.

Bizioli, G. and C. Sacchetto, eds. (2011) Tax Aspects of Fiscal Federalism: A Comparative Analysis (Amsterdam: IBFD).

Brooks, K. (2009) “Inter-Nation Equity: The Development of an Important but Underappreciated International Tax Policy Objective," in J. Head and R. Krever, eds., Tax Reform in the $21^{\text {st }}$ Century (Austin TX: Wolters Kluwer).

Carroll, M. (1978) Global Perspectives of an International Tax Lawyer: A Memoir (Hicksville NY: Exposition Press). 
Christian Aid (2013) Christian Aid's Tax Justice Strategy 2013-2016, available at http://www.christianaid.org.uk/Images/christian-aid-tax-justice-strategy-2013-2016.pdf

Cockfield, A., ed. (2010) Globalization and Its Tax Discontents: Tax Policy and International Investments (Toronto: University of Toronto Press).

Coons, C. (2001) “Wellman's 'Reductive' Justification for Redistributive Policies that Favor Compatriots," Ethics, 111 (4): 782-788.

Durst, M. (2015) The Tax Policy Outlook for Developing Countries: Reflections on International Formulary Apportionment, ICTD Working Paper 32, International Centre for Tax and Development, Institute of Development Studies, Brighton UK, February.

Eccleston, R. (2012) The Dynamics of Global Economic Governance: The Financial Crisis, the OECD and the Politics of International Tax Cooperation (Cheltenham UK: Edward Elgar).

European Union (EU) (2008) European Union Public Finance. 4th ed. (Luxembourg).

Feldman, D. (2014) “Polycentric Governance," in Handbook of Science and Technology Convergence, pp. 1-11, available at http://link.springer.com/referenceworkentry/10.1007/978-3-319-04033-2 71-1

Fuest, C. and A. Piechl (2012) "European Fiscal Union: What is it? Does it work? And are there really no Alternatives?" CESifo Forum, 13 (2): 3-9.

Genschel, P. and T. Rixen (2015) "Settling and Unsettling the Transnational Legal Order of International Taxation," in T. Halliday and G. Shaffer, Transnational Legal Orders (New York: Cambridge University Press), pp. 154-183.

Goldberg, D. (2013) The Death of the Income Tax (New York: Oxford University Press). 
Gradstein, M. and K. Konrad, eds. (2006) Institutions and Norms in Economic Development (Cambridge MA: MIT Press).

Grinberg, I. (2013) “Taxing Capital Income in Emerging Countries: Will FACTA Open the Door?” World Tax Journal, October, 325-367.

Hirschman, A. (1971) A Bias for Hope (New Haven CN: Yale University Press).

Ip, G. (2013) "The Gated Globe," Special Report, The Economist, October 12.

Kaufman, D., E. McGuirk, and P. Vicente (2012) By the People? Foreign Aid and Donor-Country Democracy, available at http://www.pedrovicente.org/aid.pdf

Kaul, I. (2012) “International Public Finance," available at http://www.ingekaul.net/pdf/10 2013/International Public Financ Fin.pdf

Kaul, I., I. Grunberg, and M. Stern, eds. (1999) Global Public Goods: International Cooperation in the $21^{\text {st }}$ Century (New York: Oxford University Press for the United Nations Development Programme).

Kaul, I., P. Conceicao, K. Le Goulven, and R. Mendoza, eds. (2002) Providing Global Public Goods: Managing Globalization (New York: Oxford University Press for the United Nations Development Programme)).

Kaul, I. and P. Conceicao (2006) The New Public Finance: Responding to Global Challenges (New York: Oxford University Press for the United Nations Development Programme).

Keynes, J. (1936) The General Theory of Employment Interest and Money (New York: Harcourt Brace).

Kleinbard, E. (2015) We are Better than This: How Government Should Spend Our Money (New York: Oxford University Press). 
Krasner, S. (1982) "Structural Causes and Regime Considerations: Regimes as Intervening Variables, International Organization, 36(2): 185-205.

Kumar, M. and D. Quinn (2012) Globalization and Corporate Taxation, IMF Working Paper WP/12/252.

Lang, M. and J. Owens (2013) The Role of Tax Treaties in Facilitating Development and Protecting the Tax Base, WU International Taxation Research Paper Series, No. 2014-13.

Lindblom, C. (1969) The Policy-Making Process (Englewood Cliffs NJ: Prentice-Hall).

Mahoney, J. (2012) Conceptualizing and Explaining Punctuated versus Incremental Change, available at http://www.google.ca/url?sa=t\&rct=i\&q=\&esrc=s\&source=web\&cd=4\&ved=0CEMQFjAD\&url=http $\% 3 A \%$ 2F\%2Fpolitics.virginia.edu\%2Fsites\%2Fpolitics.virginia.edu\%2Ffiles\%2FGradual\%2520versus\%2520Punct uated\%2520Change\%2520Circulation.doc\&ei=u07dUqOKOcqi2wWy4oGADw\&usg=AFQjCNF m2aLBk 7 $\underline{\text { SX5OHx TS-SVwxOEkw\&bvm=bv.59568121,d.aWM }}$

OECD (2010) Transfer Pricing Guidelines for Multinational Enterprises and Tax Administrations (Paris).

OECD (2013a) Addressing Base Erosion and Profits Shifting (Paris)

OECD (2013b) Action Plan for Base Erosion and Profits Shifting (Paris: OECD)

Picciotto, S. (1992) International Business Taxation (London: Weidenfeld and Nicolson).

Picciotto, S. (2013) Is the International Tax System Fit for Purpose, Especially for Developing Countries? International Centre for Tax and Development, Working Paper 13, September.

Piketty, T. (2014) Capital in the 21st Century (Cambridge, MA: Harvard University Press).

Pogge, T. (2011) “Allowing the Poor to Share the Earth," Journal of Moral Philosophy, 8: 335-352. 
Rixen, T. (2008) The Political Economy of International Tax Governance (Basingstoke UK: Palgrave Macmillan).

Sandler, T. (1997) Global Challenges: An Approach to Environmental, Political and Economic Problems (Cambridge: Cambridge University Press).

Sandler, T. (1998) "Global and Regional Public Goods: A Prognosis for Collective Action," Fiscal Studies, 19 (3): 221-247.

Sandler, T. (2001) Economic Concepts for the Social Sciences (Cambridge: Cambridge University Press).

Sandler, T. (2002) "Financing International Public Goods," in M. Ferroni and A. Mody, eds., International Public Goods: Incentives, Measurement and Financing (Dordrecht, NL: Kluwer), 81-118.

Sato, M. and R. Bird (1975) "International Aspects of the Taxation of Corporations and Shareholders," International Monetary Fund Staff Papers, 22 (July 1975): 384-455.

Sen, A. (1999) "Global Justice; Beyond International Equity," in Kaul, Grunberg and Stern, Global Public Goods, 116-115.

Shaviro, D. (2014) Fixing U.S. International Taxation (Oxford: Oxford University Press).

Sui, E., M. Nalukwago, R. Surahmat and M. Pereira (2014) Unitary Taxation in Federal and Regional Integrated Markets, ICTD Research Report 3, International Centre for Tax and Development, Institute of Development Studies, Brighton UK, September.

Siu, E., S. Picciotto, J. Mintz and A. Sawyerr (2015) Unitary Taxation in the Extractive Industry Sector, ICTD Working Paper 35, International Centre for Tax and Development, Institute of Development Studies, Brighton UK, May. 
Stiglitz, J. (2015a, b, c, d) New Theoretical Perspectives on the Distribution of Income and Wealth Among Individuals: Part I. The Wealth Residual; Part II. Equilibrium Wealth Distributions; Part III. Life Cycle Savings vs. Inherited Savings; Part IV. Land and Credit. Working Papers 21189;21190; 21191; and 21192, National Bureau of Economic Research, Cambridge MA, May.

Surrey, S. (1978) “United Nations Group of Experts and the Guidelines for Tax Treaties between Developed and Developing Countries," Harvard International Law Journal, 19 (1): 1-65.

Tanzi, V. (1995) Taxation in an Integrating World (Washington: Brookings Institution).

Thuronyi, V. (2010) "Tax Treaties and Developing Countries," in M. Lang et al., ed., Tax Treaties: Building United Nations (2006) Social Justice in an Open World (New York: Department of Economic and Social Affairs, United Nations).

Wellman, C. (2000) "Relational Facts in Liberal Political Theory: Is There Magic in the Pronoun 'My'?" Ethics, 110(3): 537-562. 